\title{
„MEIL OLI MIHKEL MEHKA JA TA NAISE NIMI HIPP“ - HARGLA KIHELKONNA TUNNUSLIKEST EESNIMEDEST
}

\author{
Taavi Pae \\ Tartu Ülikool
}

\begin{abstract}
Kokkuvõte. Siinses artiklis vaatlen Hargla kihelkonna isikunimistut, keskendudes piirkonna tunnusnimedele Mehka ja Hipp. Neist esimese järgi on tekkinud piirkonnanimi Mehkamaa ja ka etnonüüm mehkad piirkonna elanike tähistamiseks. Nimekasutuse uurimiseks koostasin Eesti Rahvusarhiivis säilitatavate Hargla kihelkonna kirikuraamatute põhjal eesnimekorpuse. Eelkõige analüüsin tunnusnimede ajalist ulatust lähtuvalt legendist, mille järgi Põhjasõja aegadel jäid piirkonda elama vaid Mehka ja Hipp ning Mõniste ümbruse rahvas pärineb suuresti sellest kooselust. Arhiiviallikad näitavad, et nimi Mehka ilmub kirikuraamatutesse alles 18. sajandi lõpus, kuid nimi võis olla varem kirikuraamatusse kirjutatud Mihklina. Eelmainitud legendi võib aga pidada kunstlikuks, mille levik on seotud eelkõige Mõniste muuseumiga, kus seda hakati tutvustama. Hargla kihelkonna üldine nimevaramu muutus aga käib kokku ühiskondlike muutustega 19. sajandi lõpukümnenditel ja sealt kadusid koos mitmete teiste toonaste tavaliste nimedega ka piirkonna tunnuseesnimed Mehka ja Hipp.
\end{abstract}

Märksõnad: Mehkamaa, Mõniste, eesnimed, etnonüümid, Mehka, Hipp

DOI: https://doi.org/10.12697/jeful.2020.11.1.06

\section{Sissejuhatus}

Käesoleva artikli peakirja esimene osa on laenatud Raimond Kolgalt (1957), kes alustab nii oma ülevaadet Mehkamaast koguteoses „Meie maa“. Asulanimedest mittelähtuvaid piirkonnanimesid ja nendega sarnaseid rahvanimetusi ehk etnonüüme pole Eestis arvukalt (nt Setomaa ja setod, Mulgimaa ja mulgid, Junnumaa ja junlased). Lisaks on mainituile sarnased veel ajaloolistest makonnanimedest tulenevad nimed, mida leidub eelkõige Põhja-Eestis (nt Virumaa ja virulased) (Pae ja Remmel 2006). Kuigi kõigi sedasorti nimede etümoloogia ja tekkelugu pole üheselt selge, siis piirkonnanime Mehkamaa ja etnonüümi mehkad lugu tundub neist kõigist erinev. Nimelt tuleneb see lokaalsest meesterahva eesnimest. 
Eestlaste eesnimede uurimise ajalugu ulatub 19. sajandi algusesse, kui Saaremaa estofiilne kirjamees Johann Wilhelm Ludwig von Luce (1814) avaldas uurimuse eestlaste nimedest. Mõnevõrra suurem huvi eesnimede vastu tekkis 19. sajandi lõpus ning 20. sajandi alguses, kui hakkasid ilmuma esimesed nimeloetelud ning soovitusnimestikud, mille eesmärgiks oli anda vanematele ideid nimepanekul. Samal ajal ilmusid ka esimesed nimede päritolu selgitavad kirjutised.

Käesoleva uurimuse spetsiifikast lähtudes omavad suuremat tähtsust eesnimede regionaalsust käsitlevad uurimused. Mitmed neist põhinevad erinevatel varauusaegsetel materjalidel. Nii näiteks on Leo Tiik (1976, 1977) käsitlenud 16. ja 17. sajandi Saaremaa nimesid, Matthias Johann Eisen (1923) ristinimesid Tartu ja Võru maakonnas 1562. aastal ning Heldur Palli (1959) 16. sajandi Harju- ja Järvamaa isikunimesid. Ühe kihelkonnaga piirduva regionaaluuringuna vaatleb Andrus Saareste (1923) Kullamaa vakuraamatu isikunimesid ning Lemming Rootsmäe (1969) Võnnu isikunimesid 18. sajandil. Suurem osa regionaalseid nimeuuringuid puudutab aga 19. sajandit ning omab siirdeid ka 20. sajandisse. Nii näiteks uuris Juhan Peegel (1959) venepäraseid eesnimesid, mis tulid kasutusele seoses elanikkonna massilise üleminekuga õigeusku, ning nende mugandumisest Ida-Saaremaa murdekeelde. Setode eesnimedest on andnud ülevaate Jaak Simm (1983) ning Eva Saar (2015). Kairit Henno (2000) on uurinud poeglaste eesnimesid Pöide kihelkonnas aastatel 1801-1840 ning Annika Hussar (2014) 19. sajandi nimekasutust Martna ja Palamuse näitel. Theodor Saar (1964) on teinud ülevaate kihnlaste eesnimedest 19. sajandist 1960. aastani, tutvustades levinumaid nimesid ning Kihnule omaseid hääldusvorme. Üle-eestiliselt on aga ajaloolist eesnimevaramut käsitletud 1840. aasta ja 1900. aasta näitel (vastavalt Pärsik ja Pae 2011 ning Hussar 2015). Regionaalseid nimeuuringuid on kahtlemata rohkemgi, nii näiteks on neid arvukalt koostatud Tallinna ülikoolis kursuse- ja lõputöödena. Käesoleva uurimuse eesmärk on anda ülevaade Hargla kihelkonna eesnimedest, keskendudes eelkõige Mõniste kandi tunnusnimedele Mehka ja Hipp. Need tänapäeval üsna harvad eesnimed on olnud iseloomulikud just Hargla kihelkonnale ja eriti just Mõniste ümbrusele. Eesnimest lähtuvalt on tekkinud etnonüüm mehkad ja piirkonnanimi Mehkamaa (Eesti etnonüümidest vt veel Pae ja Remmel 2006, Remmel 2002 ning Viikberg 2015). Analüüsimaks Hargla kihelkonna eesnimesid, on koostatud eesnimekorpus, mis hõlmab Hargla kihelkonnas pandud eesnimesid aastatel 1720-1924. 


\section{Uurimisala}

Võrumaa Hargla on Eesti lõunapoolseim kihelkond, paiknedes kitsa ribana Eesti lõunapiiril vastu Lätimaad. Kihelkond moodustati alles 1694. aastal Urvaste, Karula ja Koivaliina (Gaujiena) kihelkonna maadest. Loodusgeograafiliselt võib kihelkonna keskteljena, eelkõige piirkonna idaosas, käsitada Mustjõge, millega paralleelselt kulgeb nii teedevõrk kui ka asustussüsteem. Põhjast piirneb kihelkond Karula kõrgustiku lõunaosa metsase alaga ning lõuna pool paikneb Koivaliina metsadevöö, mida mööda kulgeb ka riigipiir. Ajaloolise, mõisatest lähtunud haldussüsteemi järgi jaguneb kihelkond kuue mõisa vahel: Koikküla, Laanemetsa, Taheva, Vastse-Roosa, Saru ja Mõniste, kusjuures kolm viimast on läbi ajaloo olnud omavahel tihedates sidemetes, kuna viimased ligi sada aastat enne mõisate võõrandamist oli neil sama omanik (Valgamaa 1932). 1920. aastal Eesti Vabariigis loodud Valga maakond poolitas Hargla kihelkonna kahe maakonna vahel. Piirkonna ajaloos on tähtsat rolli mänginud 1903. aastal käiku läinud kitsarööpmeline raudtee, mis ühendas Hargla kihelkonna rohkem Valgaga, samas soodustades ka kogu kihelkonna läbikäimist. Raudtee kasutus lõppes 1970. aastal.

Hargla kirikuküla paikneb kihelkonna keskel, jagades kihelkonna laias laastus kahte ossa - idapoolne Mõniste-Saru ja läänepoolne Laanemetsa-Koikküla piirkond. Keeleliselt on Harglas traditsiooniliselt kõneldud lõunaeesti murret, mis kuulub Võru murde läänemurrakute hulka. Siiski pole kogu kihelkond murdelises mõttes ühesugune, eristub kihelkonna ida- ja keskosa ning lääneosa. Just Mõniste-Saru keel on olnud selgelt erinev näiteks kihelkonna lääneosas kõneldud Koikküla keelest, mis sarnanes rohkem Karula kihelkonnas kõneldavaga (Nigol 1994). Ka mentaalse identiteedi mõttes on Mõniste-Saru eristunud kihelkonna lääneosast. Selle heaks näiteks on ajalehes Sakala 1904. aastal ilmunud artiklid (5. august ja 28. oktoober), kus vastandatakse Laanemetsat muu kihelkonnaga. Kuigi Mehkamaa piirkonda võib vaadelda ka laiemalt, siis n-ö õige Mehkamaana mõistetaksegi just Mõniste ümbrust. 1929. aasta 10. juuli ajalehest Rahva Sõna leiame seletuse: „Mõniste see on see õige ja päris puhastwerd Mehkamaa. Muidu nii naljawiluks ja teadmatuses kutsutakse küll kogu seda kanti, ka ümbruskonna wallad kaasaarwatud, sellase nimega, aga see ei ole õige ja puhastwerd mõnistlane annab andeks ennem kõrwakiilu, kui sellase eksimuse, et mõnda Roosa wõi muu nimega meest juletakse pidada mehkawelleks". 


\section{Metoodika}

Uurimuses kasutatavad andmed pärinevad Eesti ajalooarhiivi perekonnaloo digiteeritud allikate andmekogust Saaga (www.ra.ee/saaga). Eelkõige $^{1}$ on kasutatud luteri kiriku meetrikaraamatute sündinute ja ristitute nimekirju. Andmete kogumiseks on koguduse meetrikaraamatutest välja märgitud kõigi perioodil 1720-1924 paarisaastail sündinute eesnimed. Nimede Mehka ja Hipp esinemist uuriti kõigil aastatel ja nende kohta on andmed täpsemad. Andmeanalüüsi lihtsustamiseks ning konkreetsemate järelduste tegemiseks on töös ühendatud ortograafilised teisendid (Carl $\sim$ Karl, Hans $\sim$ Ants, Jaen $\sim$ Jaan jne), mis tulenevad tõenäoliselt kirikuõpetajate erinevast kirjutusviisist, sh vanast kirjaviisist, millelt üleminek uuele kirjaviisile toimus Harglas pärast 1891. aastat (Puss 2018). Ortograafilisteks teisenditeks on loetud ka omavahel ühe tähe võrra erinevad nimed (nt Kaarl Karl, Anna Ana, Eddo Edo jne), võõr- ja omakeelse kujuga nimed (nt Heindrich Hendrik) ning tugeva ja nõrga algushääliku poolest erinevad eesnimed (Grõt Krõõt). Enamasti juhinduti nimede ühtlustamisel Edgar Rajandi (1966 ja 2005) nimeraamatust.

Mitmiknimed on esimese nime järgi liidetud üksiknimedega, sest võib arvata, et inimest kutsuti enamasti esimese nime järgi (Rajandi ja Tarand 1976). Sellist meetodit on kasutanud varasemates nimeuurimustes näiteks Jean-Claude Sangoï (1999), kes uuris Prantsuse 18.-19. sajandi eesnimesid. Omaette küsimus on aga kirikukirjadesse läinud nimede tegelik hääldamine. Kahjuks käesoleva töö andmestik ei võimalda seda kindlaks teha ja nii peame piirduma andmetega, mis kirjas. Samas on teada, et paljudel juhtudel erines igapäevakasutuses olev nimi kirikukirjas olevast.

\section{Tulemused}

\subsection{Nimede hulk}

Ajaloolises perspektiivis on eestlaste isikunimede mitmekesisust loetud üsna väikseks. Näiteks Võnnu kihelkonna sünniregistrites esines

Kui pole teisiti mainitud, siis käsitlen artiklis Hargla luteri kiriku ristimisi, tegelikke sünde oli kihelkonnas rohkem, eelkõige pärast usuvahetusliikumist 1840. aastatel. 
18. sajandi viimasel veerandil ainult kaheksakümmend erinevat eesnime, neist 54 poisi- ja 26 tüdrukunime (Rootsmäe 1969). 1840. aasta eestlaste nimevalikut analüüsiv töö vaatleb Hargla kihelkonda kui keskmise nimemitmekesisusega piirkonda Eestis (Pärsik ja Pae 2011).

Töös vaadeldaval ajaperioodil pandi Hargla kihelkonnas $14264^{2}$ inimesele kokku 1527 eri nime; see hõlmab ka mitmiknimesid, mida oli kogu nimevalimis enamik (1128). Mitmiknimede hulk on suur, samas on nende kandjaid suhteliselt vähe. Valdavalt on tegemist kaksiknimedega (958). Mitmiknimede osakaal hakkas suurenema 1860. aastatel ning eriti palju pandi neid 19. sajandi lõpus ja 20. sajandi alguses. Taandades mitmiknimed esimese nime järgi üksiknimedeks, kahaneb eri nimede arv 530-le. Vaadates sugusid eraldi, selgub, et naiste nimede mitmekesisus on vaadeldaval perioodil suurem. Nii said 6953 ristitud tütarlast nime 294 nime hulgast (keskmiselt 23 nimekandjat ühe nime kohta) ja 7311 poisslapse nimi valiti 236 nime hulgast (keskmiselt 31 isikut nime kohta). Teisalt jälle, vaadates näiteks kümne populaarseima nime kasutussagedust, selgus, et naisenimede puhul hõlmasid need $70 \%$ nimekandjatest, samas meeste puhul 57\%. Seega, kuigi naisenimesid oli kasutusel enam, siis populaarsemaid neist kasutati sagedamini.

Kui vaadelda Hargla kihelkonna nimekasutuse mitmekesisust ajalises perspektiivis, näeme eri nimede arvu suhteliselt ühtlast jaotust kuni 19. sajandi keskpaigani (joonis 1). Teatav nimede mitmekesisuse suurenemine sai alguse 1840. aastatel. Osalt saab seda seletada talurahva üleminekuga õigeusku, millel oli ilmselt oma väike kultuurimõju ka nimedele. Oma rolli mängib ka statistiline aspekt, sest luteri kirikus ristitavate laste arv vähenes. Hargla kihelkond oli õigeusku siirdumisel üsna esirinnas. Kogu kihelkonnast läks õigeusku ligi kolmandik (33\%) ning kõige aktiivsemad usuvahetajad olid Koikküla ja Laanemetsa mõisates, kus usuvahetus puudutas $2 / 3$ elanikkonnast. Kõige vähem usuvahetajaid oli aga Saru mõisas (12\%) (Kruus 1930).

Nimede mitmekesisus hakkab kiirelt suurenema 1870. ja 1880. aastatel, seda nii Harglas kui ka teistes Eesti kihelkondades (Pärsik 2012). See on kooskõlas üldiste kultuuriliste murrangutega Eesti ühiskonnas. Vaadeldes ligi paarisaja-aastase perioodi Hargla eelisnimesid, nähtub, et naisenimede seas on olnud levinumad üldtuntud eesti nimed Ann, Liis

Kuna andmebaasi on koondatud nimed vaid paarisaastatelt, siis tegelik sündide arv on umbes kahekordne. 
ja Mari. Hargla kihelkonna tunnusnimi Hipp on neljandal kohal. Mehenimedest on lastele enim pandud Eestis üldiselt levinud nimesid Jaan ja Ants. Sageduselt kolmandal kohal on aga Henno (Heno jmt variatsioonid), mida võib samuti pidada teataval määral Hargla kihelkonnale spetsiifiliseks eesnimeks. Nimi Mehka aga pole ühelgi vaadeldaval aastal olnud esikolmikus ning ka paarisaja aasta lõikes on ta olnud populaarsuselt kümnes eesnimi. Järgnevalt aga analüüsimegi Hargla kihelkonna tunnusnimesid Mehka ja Hipp.

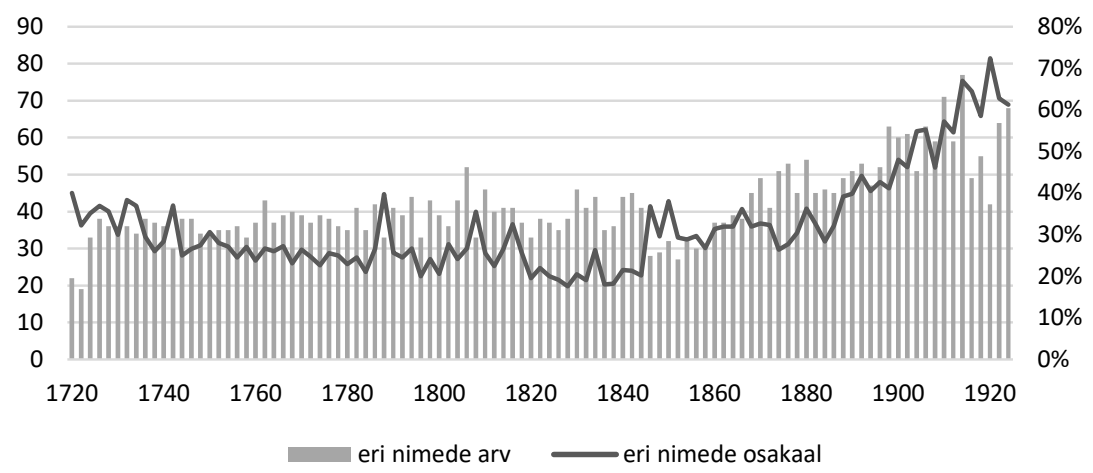

Joonis 1. Nimede mitmekesisuse muutus Hargla luteri kiriku sünnimeetrika põhjal aastail 1720-1924.

\subsection{Nimi Mehka}

Siinkohal väärib põgusalt puudutamist Mehka nime tuntus ja selleks pakub hea ülevaate ajakirjandus. Esimesed Mehka nime mainimised Eesti ajakirjanduses on 20. sajandi alguses. Sellal ilmus mitu lühiartiklit autorilt, kes peitub nime „Mehka“ taha. 1904. aasta 28. oktoobri Sakalast leiame tema sulest ka selgituse sellele lokaalsele nimele: ,Mehka on ju inimese nime, mis midagi mund ei tähenda, kui lühendatult Mihkel“. See artikkel on tegelikkuses vastulause varasemale artiklile, kus väideti, et Mõniste kandis elavad Mehkad ja Piped ${ }^{3}$. 1923. aastal saadab ajalehele Wõru Teataja lühiteate Mõnistest „Kuutsi Mehka“4. Mehkast lähtuvat

Artikkel parandas, et elavad Hiped mitte Piped; „Hargla minevik“, Sakala, 5. august 1904.

$4 \quad$ Ilmselt koolmeister Mehka Eichenbaum. 
pseudonüümi on kasutatud ajakirjanduses ka hiljem (,Mehka weli“")5. 1. märtsil 1934. aastal ilmub ajalehes Teataja suhteliselt põhjalik ülevaade Mehkamaa tuntumatest inimestest. Sellele artiklile on alla kirjutanud „Mehka poeg“6. 1928. aastal ilmub aga ajalehes Postimees kolmeosaline järjejutt Mehkamaast Herbert Tampere sulest ${ }^{\dagger}$. Sellele on ajalehes Lõuna-Eesti vastulause kirjutanud J. Altra ${ }^{8}$, mainides: „Täna tahan ma oma sünnimaad wähe kaitseda. Nimelt ilmub ühes suuremas lehes juba kolmas joru Mehkamaalt, mida kirjutab keegi H. Tampere. Too on teinud päris armsast Mehkamaast niisuguse indiaanlaste maa, et päris imestad, kuis sääl weel inimesi ei ohwerdata wõi wihamehi ei skalpeerita".

Kui vaadata Mehkamaa nime rahvaluules, siis selgub, et laiemat tuntust sellel pole olnud. Kohaloolises kirjanduses kohtab sageli Mehkamaa nime legendi, mille järgi olevat pärast suurt katku ainsana ellu jäänud Mehka-nimeline mees, kes ringi rännates kohanud naisterahvast nimega Hipp ja kõik Mõniste kandi inimesed pärinevadki just sellest kooselust (Kasesalu ja Sikk 1985). Mariko Fasteri (Eesti kohanimeraamat 2016) arvates on legend kunstlikult loodud, millega tuleb nõustuda. Mehka legend puudub näiteks ka Eesti rahvaluule arhiivis. Legendi levikus mängib rolli Mõniste muuseum ja selle rajaja Alfred Lepp ${ }^{9}$, kes võib olla legendi autor. Ennesõjaaegse värvika minevikuga A. Lepp ${ }^{10}$ töötas 1946-1957 Mõniste kultuurimaja juhatajana ja asutas 1950. aastate keskpaigas Mõniste koduloomuuseumi. Muuseumi põhitaotluseks oli anda tõetruu pilt ümbruskonna talurahva eluolust 19. sajandi II poolel, milleks püstitati rehielamu ${ }^{11}$ ja kõrvalhooned, kuhu

5 „Mõniste ühispiimameierei awamine“, Elu: Võru-Valga-Petserimaa töörahva häälekandja, 23. märts 1927; „Mõni sõna kiiresti edenevast Mõnistest“, Elu: Võru-Valga Petserimaa töörahva häälekandja, 15. jaanuar 1927; „Kiri Mehkamaalt“, Lõuna-Eesti, 2. jaanuar ja 6. veebruar 1935; „Suwiselt Mehkamaalt“, Lõuna-Eesti, 13. juuli 1934. „Mehkamaal on kangeid mehi“, Teataja, 1. märts 1934.

„Matkamärkmeid Mehkamaast“", Postimees, 13. juuli, 31. juuli 1928. H. Tampere mainib lühidalt ka lokaalset nimemoodi: „Harglal kui omaette maanurgal on ka omapärased ristinimed. Pea igal sammul puutume kokku Heno ja Mehka nimeliste meestega. Wiimasest nimest ongi Hargla kihelkond ja eriti just Mõniste wald omale nimetuse Mehkamaa saanud. Naiste nimedest figureerib kõige laiemalt Hipp“.

8 „Kurikuulus Mehkamaa“, Lõuna-Eesti, 18. august 1928.

9 Alfred Lepa emapoolsete vanavanemate nimi oli Mihkel (võimalik, et kutsuti Mehkaks) ja Hipp.

10 Alfred Lepast enne II maailmasõda vt Vihuri 2007.

11 Rehielamu ehitas 1879. aastal Mehka Kalamees. 
koguti tööriistu ja muud pärandvara. Rehetuppa aga meisterdas A. Lepp mannekeen-eksponaadid Mehka ja Hipe viitega sagedastele kohalikele eesnimedele, mida toetas siis kunstlegend.

Nime tuntuse kohta leiame taustateavet veel mitmetest meie keelekogudest. Nii on Eesti Keele Instituudi kohanimekartoteegis ${ }^{12}$ mainitud „Mehkamaa - Mõniste valla lääneosa ja Hargla kiriku ümbrus, kus meestel palju Mehka (Mihkel) nimeks" ning võru-eesti sõnaraamatus mehka - Mõniste valla meeste hüüdnimi (Võro-eesti synaraamat 2002). Andrus Saareste (1958) tunneb samuti sõna mehkad, mis käib Hargla kihelkonna, eriti Mõniste valla rahva kohta. Sama seletust kasutab ta sõna hiped kohta. Varasemad eesti trükitud keelekogud Mehkamaa nime ei tunne. Nii leiame Ferdinand Johann Wiedemanni (1973) sõnaraamatus küll viite Mõniste kandi etnonüümile - loks-munnlased ${ }^{13}$, kuid selle tähendus jääb selgusetuks ning pigem on tegemist hariliku halvustava väljaütlemisega, mille F. J. Wiedemann on otsustanud siiski ära trükkida. Selle etnonüümi kasutusulatus on ilmselt olnud siiski vähene. F. J. Wiedemannilt leiame siiski Mehkale lähedase eesnime Mihka. Julius Mägiste (1929) annab selle nimevormi viitega F. J. Wiedemannile, samas täiendusega, et lõuna-eesti murdeis võib see esineda vormina Mehka. Mihka variandi leiame ka E. Rajandilt (1966 ja 2005). Kohalikus murdekeeles võib esisilbi $i$ madalduda $e$-ks, andeski nimekuju Mehka.

Mehka on niisiis murdeline vorm mehenimest Mihkel ${ }^{14}$. Mihkli nime võib ürikutest leida 15. sajandist peale ja ta on olnud sellest ajast peale üks eestlaste lemmiknimesid. Nii näiteks oli 19. sajandi I veerandil Tartus 13\% meestest Mihklid, mis omakorda tõi kaasa ka perekonnanime Mihkelson suhtelise arvukuse (Rajandi ja Tarand 1976). Ülemaailmselt tuntud nime algupära on heebrea keeles, kus see tähendab jumalikku. Lisaks põhinimele on meil kasutusel olnud veel rida teisendeid, nagu Mihka, Mihkael, Mihkel, Miihkli, Mike, Mikk, Mikli, Miko/Miku (Rajandi 1966/2005). Kihnu kultuuriruumis on tänaseni kasutusel regionaalne nimevariant Mitta (Saar 1964). Siinkohal on meil praegu raske

12 Eesti Keele Instituudi kohanimekartoteek. Saadaval internetis $<$ http://heli.eki.ee/kohanimed/>. Vaadatud 25.05.2020.

13 loks-munn, Spitzname für Einen aus Menzen. F. J. Wiedemanni sõnaraamatu 1. trükis, mis ilmus 1869. aastal, nimetust ei esine. Nimetus esineb 2., täiendatud trükis, mis ilmus postuumselt 1893 ja mida redigeeris F. J. Wiedemanni juhiste järgi Jakob Hurt.

14 Siiski esineb Mihkli ja Mehka nimesid Hargla meetrikates ka paralleelselt. 
öelda, kas kirikuraamatus olnud Mihklid olid tavaelus ikkagi Mehkad või mitte. Seda, et Mihklit Mehkaks kutsuti, toetab artikli pealkirjas toodud Raimond Kolga mõttearendus. 1929. aastal Alfred Kivirähki poolt kirja pandud Hargla kihelkonna ajaloolisest traditsioonist leiame ka märke, et n-ö ametlik ja rahvakeelne nimi erinevad. Nimelt on seal küsitletud kooliõpetajat Mehka Eichenbaumi, samas on kooli õpetajate nimekirja märgitud: „Mihkel (ise nimetab end Mehkaks)...."15. Mehkale leiame mõningaid tähendusi ka teistest keelekogudest. Nii annab eesti slängi sõnaraamat ${ }^{16}$ Mehka üheks tähenduseks 'vahva' või ka 'tore'. Seda tähendust on küsitavalt seostatud ka laenuga vene keelest ${ }^{17}$ (Eesti etümoloogiasõnaraamat 2012). Eesti murrete sõnaraamatu ${ }^{18}$ järgi on mehka mitmes kihelkonnas tähendanud 'maitsev, hea' (Kuu, Lüg, Jõh, IisR) ja Kuusalus ka 'mõnus, muhe'. Helmes on niiviisi nimetatud metstuvi. Tuvi tähendusele viitab ka Mart Mäger (1994). Tänasel päeval on Mehka kasutusel mitteametliku külanimena endise Mõniste raudteejaama ümbruses. Sealne pood, mida varemalt ka Jaama poeks kutsuti, sai pärast Eesti Vabariigi taasiseseisvumist Mehka nime ja kuigi pood on ammu suletud, meenutab (ja ilmselt ka süvendab) hoonel asuv Mehka poe silt toponüümi kasutust. Kohalikel valimistel kandideeris aastatel 1996-2002 valimisliit Mehkamaa ning vallavalitsuse meiliaadresski oli aastatuhande esimesel kümnendil kohapealsest ajaloolisest nimest mõjutatud ${ }^{19}$. Valla ajaleht oli samuti Mehkamaa ${ }^{20}$. Lõuna-Eesti üks suuremaid metsa- ja aiatööriistade müüjaid on AS Mehka ${ }^{21}$ ning selle omanike juured viivad just Mõniste kanti. Seega võime tõdeda, et Mehka nimi on tänaselgi päeval aktiivselt kasutusel.

Eesnime Mehka seoseid etnonüümi ja piirkonnanimega meetrikaraamatute baasil on varem vaadatud surmameetrikast lähtuvalt (Pae ja Remmel 2006). Vaatleme nüüd lähemalt Mehka nime panekut Hargla

15 Hargla kihelkonnast 1927. a. suvel kogutud ajalooline traditsioon. Alfred Kivirähk. Saadaval Internetis $<$ https://folklore.ee/pubte/ajaloolist/hargla/>. Vaadatud 25.05.2020.

16 Esimene eesti slängi sõnaraamat. Saadaval Internetis $<$ http://www.eki.ee/dict/slang/ $>$. Vaadatud 25.05.2020.

17 Vene keeles smeh 'naer'.

18 Eesti murrete sõnaraamat. Saadaval Internetis $<$ http://www.eki.ee/dict/ems/ems.html>. Vaadatud 25.05.2020.

19 vald@mehka.werro.ee

20 Ajaleht Mehkamaa ilmus aastail 2006-2017. Kokku anti välja 137 numbrit. Praegu ilmub digikujul Mehkamaa infoleht ja tegutseb ka Facebooki grupp Mehkamaa.

21 Alguses oli AS-il Mehka Võrus kauplus nimega Hipe. 
kihelkonna sünnimeetrika ${ }^{22}$ põhjal (joonis 2). Esimest korda esineb Mehka Hargla sünnimeetrikas 1765. aastal ja seda ühel juhul' ${ }^{23}$. Tähelepanu väärib seejuures asjaolu, et üks ristivanematest kannab Mehka nime, mis viitab selle nime varasemale kasutusele. Ka Mehkade sünnikannetes aastail 1777-1787 on enamikul üks ristivanem olnud Mehkanimeline mees. Nimepanekul vaderite nimest lähtumine on olnud tavapärane paljudes Eesti piirkondades (Hussar 2009). Kui 1777. aastast alates on nime Mehka pandud kuni sajandi lõpuni, siis 19. sajandi esimesel kümnendil pole seda nime kasutatud. 1812. aastast jällegi kuni 1878. aastani on Mehka nime andmine olnud peaaegu järjekindel. Samas pole ta ühelgi aastal olnud populaarseimate nimede hulgas. Hargla maetute ja laulatatute nimekirju kontrollides selgus, et sinna ilmuvad Mehkad umbes samal ajal kui sünnimeetrikasse. Esimene Harglas laulatatud Mehka on Kalli Henno p. Mehka Mõniste vallast 1777. aastal24. 1786. aastal leiame aga 70 aasta vanuses surnud Kilvako Mehka ${ }^{25}$.

Juhuslikke nime Mehka sissekandeid leiab siiski ka varasemast ajast. Nii on 1720. aastal sündinud Henriku isaks Mehka Peep Laanemetsast $^{26}$. Eelnevast võib järeldada, et Mehkad on olemas olnud juba enne 1770. aastaid, aga siis on nad kirja pandud arvatavasti Mihklitena. Märkimist väärib aga see, et 1780. aastatel ei hakka Mehka kirikukirjades mitte Mihklit asendama, vaid eksisteerib kirikuraamatutes paralleelselt nimevormidega Mihkel, Mihkli, Michli ja Michel. Hargla kihelkonna hingerevisjoni materjalides 1795. aastast puuduvad Mehkad aga jälle peaaegu täielikult ${ }^{27}$. Siinkohal on oluline teada, et hingerevisjonide kirjapanijateks olid võõrad, väljastpoolt kihelkonda pärinevad ametnikud, kes lugesid kohapealsed murdeerinevusest tingitud nimevormid ilmselt üheks. Nime Mehka puudumist varastes meetrikaraamatutes võib seletada ka pastori erineva nimekirjutustavaga. 1770. aastast on Hargla kirikuraamatutesse sissekanded tehtud ühe ja sama käekirjaga. Siis sai Hargla pastoriks Johann Friedrich Hartmann (oli Harglas pastoriks 1770-1788; Die evangelishen ... 1977). Väärib märkimist, et Mehka nimevorm ilmub kirikuraamatutesse just tema

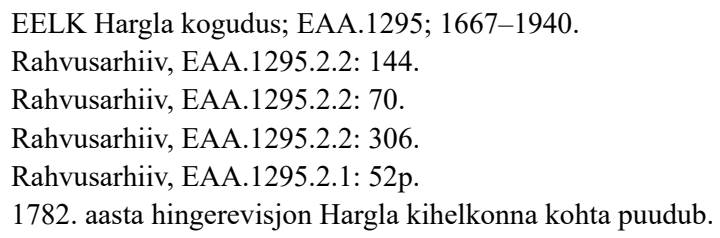


ametiajal, aga alles ligemale 10-aastase staaži järel. Nime Mehka varasemat kasutust kinnitavad ka muud allikad. 1758. aasta Mõniste mõisa vakuraamatus leiame Mõniste külast peremees Kirbu Mehka ${ }^{28}$.

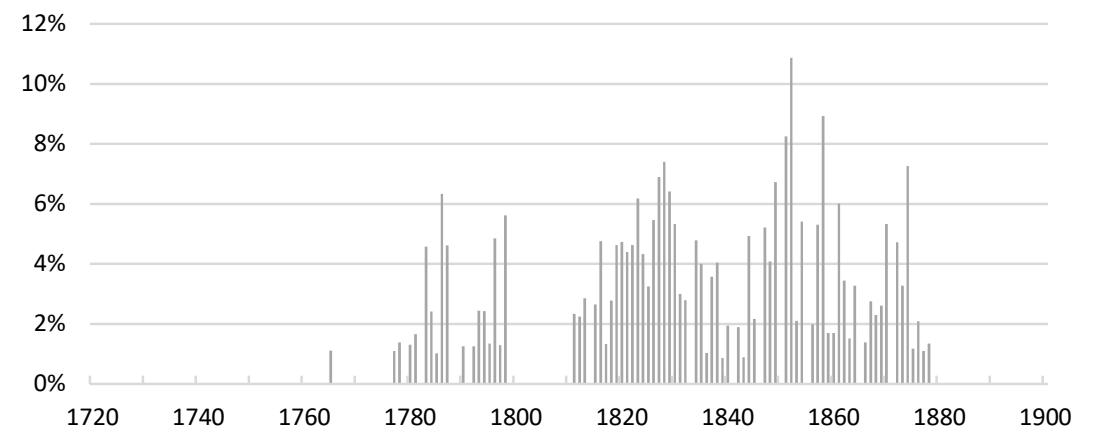

Joonis 2. Mehka nime saanute osakaal Hargla kihelkonna poisslastest.

\subsection{Nimi Hipp}

Järgnevalt vaatame lühidalt ka teist Hargla tunnusnime - Hipp. Hargla sünnimeetrika hakkab pihta septembrist 1717, seejuures on ristimisi algul märkimisväärselt vähe $(1717,4 ; 1718,7)$. Esimene Hipp (Hibb) on ristitud septembris 1718, aga nimi esineb juba 1717. aastal ühe ristitud lapse ema nimena. Valdavalt on vaadeldaval perioodil pandud aastas 5-10 korral eesnime Hipp, mis suhtarvuna tähendab, et selle nime on saanud keskmiselt iga kümnes laps. Nagu nähtub jooniselt 3, on selle regionaalse tüdrukunime populaarsus olnud suhteliselt ühtlane alates sünnimeetrika algusest 1870. aastateni, kui selle nime panek vaikselt hääbus. Seega võib öelda, et nime Hipp ajalugu läheb kindlasti tagasi 18. sajandi algusesse ja nimi on olnud pooleteise sajandi jooksul ka suhteliselt populaarne.

Hipp pole siiski seotud ainult Hargla kihelkonnaga. 1840. aastal näiteks anti nime Hipp lastele ka naaberkihelkondades Urvastes ja Rõuges, kuigi seal on pigem tegemist üksikjuhtudega ja sellist populaarsust nagu

28 Rahvusarhiiv, EAA.567.3.169: 9p. 
Harglas pole see mujal saavutanud (Pärsik 2011). Juhuslikult on nime Hipp pandud ka Põhja-Eestis ${ }^{29}$.

Ilmselt võib nime Hipp pidada nime Epp (Hebo, Hebu) lokaalseks variandiks. Õigeusu kirikukirjades muutus Hipp Agrippinaks. Siiski ei saa käsitletavat nime pidada vaid naisenimeks. Nii märgib F. J. Wiedemann seda ka poisinimena ja Oskar Kallas (1921) on seda nime maininud ununevate poisinimede rubriigis, mida võiks ehk jälle tarvitusele võtta. O. Kallas on lisanud ka nime käänamise, mis erineb tavapärasest naisenime Hipp : Hipe $\sim$ Hipõ lõunaeestilikust vormist. Nii peaks mehenimi käänduma Hipp : Hipu. Jaak Simm (1983) on nime Hipp käsitlenud samuti mehenimena ja teisendina vene nimest Filipp, kus esihäälik on asendunud (Filipp > Hilip, Hilp, Hipp, Hippo; vt ka Saar 2015).

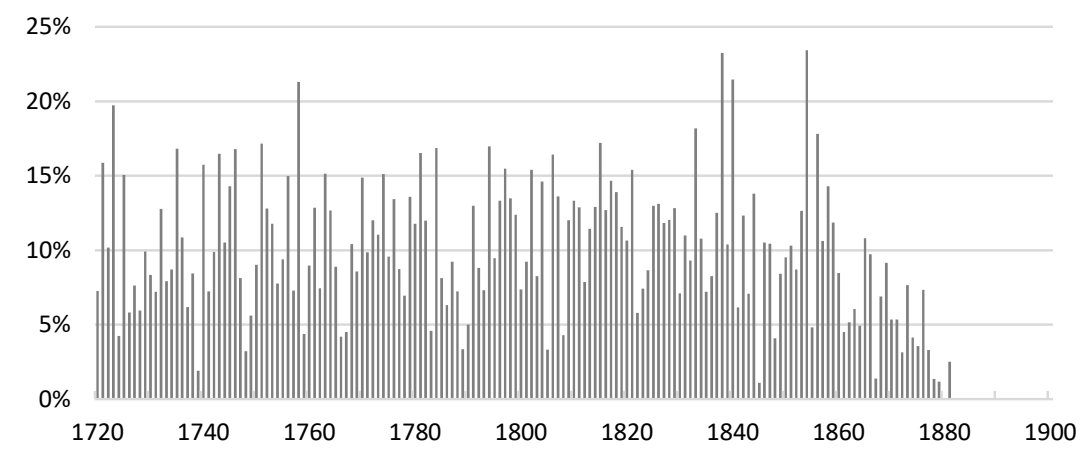

Joonis 3. Nime Hipp saanute osakaal Hargla kihelkonna tütarlastest.

\section{Kokkuvõte ja järeldused}

Mehenimest Mehka on niisiis tekkinud piirkonnanimi Mehkamaa ja ka etnonüüm mehkad. Mehka nimi oli Hargla kihelkonnas kasutusel kindlasti 18. sajandi lõpus. Samas kinnitavad üksikud teated, et seda nime on kasutatud ka varem, kuid enne 1770. aastaid olid vähemalt osad neis kirikukirjades märgitud Mihklitena. Samas annavad arhiiviallikad alust väita, et Mihkli ja Mehka näol on siiski olnud tegemist erinevate nimetraditsioonidega, sest nad esinevad ka paralleelselt. Osalt mängib siin ilmselt rolli kirjapanijate teadmine n-ö ametlikest eesnimedest ja

29 Rahvusarhiiv, EAA.1228.2.1: 6, viite eest tänan Fred Pussi. 
nende tegelikust murdelisest kasutusest. Kuigi 18. sajandi teisel poolel leidub Mehkasid juba paljudes Hargla kihelkonna mõisates, siis on see nimi väga tugevalt seotud Mõniste-Saru kaksikmõisaga ning arvatavasti sealt mujale Hargla kihelkonda levinud. Nimi Mehka polnud uurimisperioodil küll Hargla kihelkonna populaarseimate nimede hulgas, siiski on ta pea järjepidevalt olnud kirikukirjades esindatud 1811. aastast kuni 1879. aastani, kui see nimi sünnisissekannetest kaob.

Kindlasti ei saa öelda, et piirkonnanimi Mehkamaa oleks Eestis üldtuntud. Sarnaste üldtuntud Eesti piirkonnanimedena võib Eestis üldse käsitada vaid Setu- ja Mulgimaad. Siiski on see teada-tuntud eeskätt lõunaeestikeelses kultuuriruumis ning tuntust suurendab kindlasti ka Mõniste muuseum. Viimase kaudu on ilmselt läinud levima legend, mille järgi Põhjasõja järel jäid piirkonda elama Mehka ja Hipp ning sellest kooselust pärineb Mõniste elanikkond. Piirkonnanimena ja etnonüümina tulid Mehkamaa ja mehkad kasutusele 19. sajandi lõpus, kui suurenes kihelkondadevaheline läbikäimine. Omalaadne mehenimi jäi kindlasti naabritele kõrva ja silma ning nii laienesid need piirkonna tunnusnimedeks, algselt ilmselt pilkavas tähenduses. Lisaks omapärasele mehenimele toetas etnonüümi ja piirkonnanime teket Mõniste ümbruse keel.

Mõnevõrra laiema levikuga nimena, aga siiski eelkõige Hargla tunnusnimena, võib käsitada naisenime Hipp, mis on murdeline nimevorm naisenimest Epp. Selle nimekuju ajalugu on kirikuraamatute põhjal selgesti tagasi viidav Põhjasõja aegadesse. Nimi Hipp on olnud enamikul aastatel ka väga populaarne. Kuigi nime sissekannete algus kirikuraamatusse erineb ajaliselt paljuski Mehkast, siis nime viimane sissekanne kirikuraamatus on Mehkast vaid paar aastat hilisem - 1881. Nende Hargla tunnusnimede kadu kajastab suuremat nimemoe muutust, mis toimus nii Harglas kui ka kõigis teistes Eesti piirkondades.

Kahtlemata on nime Mehka ja Hipp näol tegemist omalaadsete piirkondlike eesnimedega. Eesti etnonüümide ja piirkonnanimede hulgas on mehkad ja Mehkamaa Eestis ainsad, mis on kujunenud eesnimest.

\section{Tänuavaldused}

Tänan Kristiina Tiidebergi ja Age Poomi abi ning retsensente kasulike märkuste eest. Artikli valmimist on toetanud personaalse uurimistoetuse rühmagrant PRG306. 


\author{
Aadress \\ Taavi Pae \\ Tartu Ülikool, geograafia osakond \\ Vanemuise 46 \\ 51014 Tartu \\ E-post: taavi.pae@ut.ee
}

\title{
Kirjandus
}

Die evangelischen Prediger Livlands bis 1918. Köln, Wien: Böhlau, 1977.

Eesti etümoloogiasõnaraamat. Peatoimetaja Iris Metsmägi. Tallinn: Eesti Keele Sihtasutus, 2012.

Eesti kohanimeraamat. Toimetanud Peeter Päll, Marja Kallasmaa. Tallinn: Eesti Keele Sihtasutus, 2016.

Eisen, Matthias Johann (1923) „Risti- ja sugunimed Tartu-Võru maakonnas a. 1582“. Eesti Keel 1, 4-10.

Henno, Kairit (2000) „Poeglaste eesnimed Pöide Eesti koguduse 1801.-1840. aasta sünniregistreis“. Emakeele Seltsi aastaraamat 44-45, 30-41.

Hussar, Annika (2009) „Changes in naming patterns in 19th century Estonia. Discarding the names of parents and godparents“. Rmt Wolfgang Ahrens, Sheila Embleton, and André Lapierre, eds. Names in multilingual, multi-cultural and multi-ethnic contact: proceedings of the 23rd international congress of onomastic sciences. August 17-22, 2008. York University, Toronto, Canada, 519-525. Toronto, Canada: York University.

Hussar, Annika (2014) „Muutused eesnimekasutuses XIX sajandil Martna ja Palamuse näitel“. Emakeele Seltsi aastaraamat 57, 35-59. https://doi.org/10.3176/esa57.03

Hussar, Annika (2015) „Eestlaste eesnimed 1900. aastal““. Emakeele Seltsi aastaraamat 60, 51-73. https://doi.org/10.3176/esa60.03

Kallas, Oskar (1921) Sadakakskümmend uut ristinime. Tartu: Postimees.

Kasesalu, Heini ja Maria Sikk, koost. (1986) Võrumaa ja võrulased. Tallinn: Perioodika.

Kolk, Raimond (1957) „Mehkamaa“. Rmt.B. Kangro, V. Uibopuu, toim. Meie maa IV. Lõuna-Eesti, 100-101. Lund: Eesti Kirjanike Kooperatiiv.

Kruus, Hans (1930) Talurahva käärimine Lõuna-Eestis XIX sajandi 40-ndail aastail. Tartu: Eesti Kirjanduse Selts.

Luce, Johann Wilhelm Ludwig von (1814) „Etwas über den ehstnischen Calender“. Beiträge zur genauern Kenntniß der ehstnischen Sprache 3, 47-52.

Mäger, Mart (1994) Linnud rahva keeles ja meeles. Tallinn: Koolibri.

Mägiste, Julius (1929) Eestipäraseid isikunimesid. Tartu: Akadeemilise Emakeele Seltsi kirjastus.

Nigol, Salme (1994) Hargla murraku konsonantism. Tallinn: Eesti TA Eesti Keele Instituut. 
Pae, Taavi ja Mari-Ann Remmel (2006) „Eesti etnonüümid, võrdnimed ja piirkonnanimed“. Keel ja Kirjandus 3, 177-190.

Palli, Heldur (1959) „Eesti isikunimedest Harju- ja Järvamaal XVI sajandil“. Keel ja Kirjandus 10, 595-608.

Peegel, Juhan (1959) „Vene päritolu eesnimede mugandumisest Ida-Saaremaa murretes“. Emakeele Seltsi aastaraamat 5, 97-101.

Puss, Fred (2018) „Kirjaviisivahetus kirikuraamatutes“. Emakeele Seltsi aastaraamat 63, 166-200. https://doi.org/10.3176/esa63.08

Pärsik, Liisi ja Taavi Pae (2011) „Eesnimede piirkondlikud erinevused Eestis 1840. aastal“. Akadeemia 3, 511-536.

Pärsik, Liisi (2011) „Lõunaeestlaste eesnimedest 1840. aastal“. Tartu Ülikooli LõunaEesti keele ja kultuuriuuringute keskuse aastaraamat 9-10, 138-151.

Pärsik, Liisi (2012) Eestlaste eesnimede ajalis-ruumilised muutused 19. sajandi II poolel. Tartu Ülikooli geograafia osakond, magistritöö.

Rajandi, Edgar (1966) Raamat nimedest. Tallinn: Eesti Raamat.

Rajandi, Edgar (2005) Raamat nimedest. Tallinn: Tammerraamat.

Rajandi, Edgar ja Helmut Tarand (1976) „Eesti nimi läbi sajandite“. Rmt. Mart Mäger, koost. Keel, mida me uurime, 131-140. Tallinn: Valgus.

Remmel, Mari-Ann (2002) „Viru mees viljapulli , Harju mees aganapulli. Piirkondlike suhete kajastumisest eesti rahvapärimuses“. Mäetagused 21, 141-192.

https://doi.org/10.7592/MT2002.21.remmel

Rootsmäe, Lemming (1969) „Võnnu kihelkonna isikunimed XVIII sajandil“. Keel ja Kirjandus 10, 623-624.

Saar, Eva (2015) „Vene õigeusu eesnimed vadja, isuri ja seto keeles“. Emakeele Seltsi aastaraamat 61, 92-98. https://doi.org/10.3176/esa61.08

Saar, Theodor (1964) „Kihnlaste eesnimedest“. Emakeele Seltsi aastaraamat 10, 227 246.

Saareste, Albert (1923) „400-a. vanune keeleline leid Eestis“. Eesti Keel 4, 97-104; 5-6, 136-149.

Saareste, Andrus (1958) Eesti keele mõisteline sõnaraamat I: A-kogu. Stockholm: Vaba Eesti.

Sangoï, Jean-Claude (1999) „Forename, family and society in southwest France (eighteenth-nineteenth centuries)“. The History of the Family 3, 239-259. https://doi.org/10.1016/S1081-602X(99)00015-9

Simm, Jaak (1983) „Setu eesnimesid“. Emakeele Seltsi aastaraamat 26-27, 92-98.

Tiik, Leo (1976) „Nimesid Saaremaalt XVI ja XVII sajandist“. Keel ja Kirjandus 7, 413-418.

Tiik, Leo (1977) „Isikunimede mugandid Saaremaal XVI ja XVII sajandil“. Keel ja Kirjandus 5, 284-288.

Valgamaa: maateaduslik, tulunduslik ja ajalooline kirjeldus. A. Tammekann, A. Luha ja E. Kant, toim. Tartu: Eesti Kirjanduse Selts, 1932.

Vihuri, Veiko (2007) Hugo Bernhard Rahamägi, Eesti Evangeelse Luterliku Kiriku teine piiskop 1934-1939. Tartu: Tartu Ülikooli Kirjastus. 
Viikberg, Jüri (2015),,Vandiraiujad, ubamulgid, mehkad ja setud - ühed eestlased kõik. Märkmeid eestlaste paikkondlikust identiteedist“. Oma Keel 5, 32-36.

Wiedemann, Ferdinand Johann (1973) Eesti-saksa sõnaraamat: Estnisch-deutsches Wörterbuch. 4., muutmata tr teisest, Jakob Hurda redigeeritud väljaandest. Tallinn: Valgus.

Võro-eesti synaraamat $=$ Võru-eesti sõnaraamat (2002) Kokko pandnuq Jüvä Sullõv. Tarto-Võro: Võro Instituut.

\begin{abstract}
Taavi Pae: "We used Mehka instead Mihkel and his wife's name was Hipp" - On the characteristic first names of Hargla parish. In this article, I analyse first names in the Hargla parish (Võru county in Southern Estonia), focusing on two historically typical first names for the region: Mehka and Hipp. The first of these has been used to identify the whole area (Mehkamaa) as well as an ethnonym (mehkad). The author compiled a firstname corpus based on the Hargla parish register kept in the Estonian National Archives. One motive for the analysis was to verify the folklore of only two people in the area - a Mehka and a Hipp - surviving the Great Northern War, with the full population of the area descending from this partnership. The archive materials indicate that Mehka appeared in the parish register only in the late 18th century. There are several references to the earlier use of that name, but in the parish record they were marked as Mihkel. Nonetheless, the 'folklore' can be considered artificial with its spread primarily related to the Mõniste Museum founded in 1957. The general change in the name system of Hargla parish coincided with the social changes in the late 19th century. The regional first names Mehka and Hipp disappeared and the names became longer and more German-like.
\end{abstract}

Keywords: Mehkamaa, Mõniste, first names, ethnonyms, Mehka, Hipp 